\title{
Stressors in nurses working in Intensive Care Units
}

\author{
Vitor Manuel Costa Pereira Rodrigues ${ }^{1}$ \\ Andreia Susana de Sousa Ferreira²
}

This is a descriptive cross-sectional study. The sample consisted of 235 nurses from two intensive care units in Porto (Portugal). The purpose of this study was to identify stressors for nurses working in intensive care units. The data was collected using the following: i) a questionnaire (for socio-demographic variables, physical aspects of work and variables related to the work context; ii) Interpersonal Work Relations Scale; iii) Nurse Stress Index. Nurses in the early phase of their career have higher stress levels $(\bar{X}=81)$. An inadequate physical work structure leads to higher stress levels $(X=83)$. The worse the interpersonal relations are, the higher stress levels nurses feel (Spearman correlation coefficient $=-0.331$ ). Nurses who have a bad relationship with their work superiors view the dimension "Support and Organizational Involvement" as a stressor (Student's t test, $p<0.001$ ).

Descriptors: Stress; Nursing; Intensive Care Units.

\footnotetext{
${ }^{1}$ Ph.D. in Biomedical Sciences, Professor Coordinator with Aggregation, Escola Superior de Enfermagem, Universidade de Trás-os-Montes e Alto Douro, Vila Real, Portugal. E-mail: vmcpr@utad.pt.

${ }^{2}$ RN, Hospital de S. João, Porto, Portugal. M.Sc. in Management of Health Services. E-mail: andreiasus@hotmail.com.
}

Corresponding Author:

Vitor Manuel Costa Pereira Rodrigues

ESEnfVR - Universidade de Trás-os-Montes e Alto Douro

Lugar do Tojal

Lordelo

5000-232 Vila Real - Portugal

E-mail:vmcpr@utad.pt 


\section{Fatores geradores de estresse em enfermeiros de Unidades de Terapia Intensiva}

Trata-se de estudo do tipo descritivo e transversal, englobando amostra com 235 enfermeiros, pertencentes a duas unidades de terapia intensiva da cidade do Porto, Portugal, e teve como objetivo conhecer alguns fatores geradores de estresse em enfermeiros que trabalham em unidades de terapia intensiva. Na recolha de dados, utilizou-se: i) questionário de autopreenchimento (para as variáveis sociodemográficas, para os aspectos físicos do serviço e para as variáveis relacionadas ao contexto de trabalho); ii) a escala das relações interpessoais no trabalho e iii) a nurse stress index. Pelos resultados, observa-se que enfermeiros, em início de carreira, têm níveis de estresse mais elevados ( $\bar{X}=81$ ); estrutura física não adequada conduz a níveis de estresse mais elevados ( $X=83)$; quanto pior é a relação interpessoal maiores são os níveis de estresse (coeficiente de correlação de Spearman=-0,331). Os enfermeiros que estabelecem má relação com as chefias percepcionam a dimensão apoio e envolvimento organizacional como fonte geradora de estresse (teste t de Student, $p<0,001$ ).

Descritores: Estresse; Enfermagem; Unidades de Terapia Intensiva.

\section{Factores generadores de estrés en enfermeros en unidades de terapia intensiva}

Se trata de un estudio de tipo descriptivo y transversal, en total la muestra fue constituida con 235 enfermeros pertenecientes a dos unidades de terapia intensiva de la ciudad del Porto (Portugal), con el objetivo de conocer algunos factores generadores de estrés de enfermeros que trabajan en unidades de terapia intensiva. En la recolección de datos se utilizó: 1) un cuestionario de auto llenado (para las variables sociodemográficas, para los aspectos físicos del servicio y para las variables relacionadas con el contexto de trabajo); 2) la Escala de las Relaciones Interpersonales en el Trabajo; y 3) la Nurse Stress Índex. Se identificó que los enfermeros en inicio de carrera tiene niveles de estrés más elevados ( $\bar{X}=81$ ); que una estructura física inadecuada conduce a niveles de estrés más elevados $(X=83)$; que cuanto peor es la relación interpersonal, mayores son los niveles de estrés (Coeficiente de correlación de Spearman =-0,331); que los enfermeros que establecen una mala relación con los jefes perciben la dimensión "Apoyo y envolvimiento organizacional" como fuente generadora de estrés ( $t$-Student, $p<0,001$ ). Se recomienda implementar programas de intervención para la gestión del estrés ocupacional, que debe integrar todas las áreas operacionales y envolver a todos los colaboradores.

Descriptores: Estrés; Enfermería; Unidades de Terapia Intensiva.

\section{Introduction}

Stress is an essential part of human beings' mechanisms and can be considered a stimulant, a source of satisfaction and balance. It is the adaptive response to any requirement the environment or the person him/herself poses ${ }^{(1)}$. Stress is the condition that results when person/environment transactions make the subject feel a discrepancy between the demands of a given situation and biological, psychological or social resources $^{(2)}$. Adaptation obeys to the principles of the economy of functions, the minimization of efforts and the search for wellbeing, giving rise to stress when these principles are not respected. When the person is confronted with an event that is assessed as a stressor, a process occurs that involves the entire organism. Stress induces emotions, alters observable behavior and interferes with biological and cognitive mechanisms. 
Greater stress intensities and longer stress periods enhance these changes even more ${ }^{(3)}$. In their lifetime, people experience stress situations and try to deal with these realities in different ways, using strategies to cope with stress-inducing situations - so-called mechanisms of coping with or adapting to stress ${ }^{(4)}$. Professional activity can involve positive and negative aspects. When human beings like their work, they are satisfied with their salary, with the work environment and the group of colleagues, among other variables, which also constitute a source of psychological growth and personal accomplishment. Work not only represents a source of economic income, but is also connected with important psychological aspects that help to enrich one's selfesteem. It can equally be loaded with negative aspects though, due to the characteristics of the work the person performs, constituting a source of stress that gradually wears people out(3).

The National Institute of Occupational Safety and Health defines work-related stress, also called professional or occupational stress, as a consequence of the disequilibrium between work demands and workers' skills/resources or needs or, also, work-related stress represents a patterns of an emotional, cognitive, behavioral and physiological reaction to harmful and adverse components of the work context ${ }^{(5)}$. Some work environment and organization characteristics can represent risk factors for stress, which $\operatorname{are}^{(6-8)}$ : i) organizational culture and function-related aspects; ii) role ambiguity; iii) role conflict; iv) insufficient tasks attributed; v) responsibility for people; vi) insecurity at work, aspects related to career evolution, feeling of injustice regarding one's own salary and delayed promotions; vii) lack of participation in work-related decision making; viii) deficient interpersonal relations with superiors, subordinates or colleagues; ix) exposure to violence at work; $x$ ) home/work interface and $x i$ ) shift and night work.

In the health sector, occupational stress is a highly present aspect and, among all health professionals, nurses are the most exposed(3). In the hospital context, intensive care units (ICU) are particularly stressful environments, serving for care delivery to critical patients, who require permanent and specialized medical and nursing care. They are characterized by demanding routines, sophisticated and noisy equipment, mostly without natural light and high chances of death and pain ${ }^{(9)}$. Also, health professionals' work conditions, motivation and wellbeing have been relegated to the background(10).
An intensive care unit comprises a set of functionally grouped elements, aimed at care delivery to severe or high-risk patients, who continuously need medical and nursing care, besides specialized equipment and human resources(11). ICUs are complex units under continuous monitoring, where patients admitted in severe conditions or with decompensation of one or more organic systems can recover through intensive support and treatment. This is a reserved and singular space in the hospital, as the type of patients admitted required continuous monitoring and surveillance of all vital parameters ${ }^{(12)}$. ICU work is complex and intense, and nurses should be prepared to deliver care to patients with important hemodynamic alterations at any time, which demand specific knowledge and great skill to make decisions and put them in practice in due time ${ }^{(13-14)}$. Intensive care nurses take charge of patient care in emergency as well as life support cases and, therefore, independently of the diagnosis or clinical context, they should be apt to use a comprehensive approach, in which experience should be combined with technical and scientific knowledge(15-16).

Based on the above, the research question this study focuses on is: what stressors do nurses at two intensive care units face in the city of Porto, Portugal?

\section{Methods}

This is an exploratory, descriptive and crosssectional study. The population comprised all nurses working at adult intensive care units of Hospital de São João (hereinafter called hospital A) and Centro Hospitalar do Porto (hereinafter called hospital B). From the universe of 319 nurses, 235 answered questionnaires were obtained, corresponding to a sample of $67.39 \%$ of the population. As an exclusion criterion, professional experience of less than six months was adopted, as that is the mean time for integration at intensive care units in Portuguese hospitals.

The following data collection instruments were used i) self-applied questionnaire, comprising 22 questions, to assess socio-demographic variables, variables related to physical aspects of work and some variables related to the work context; ii) the interpersonal work relations scale (ERIT), with 17 items and a Likert-scale structure ranging from 1 to 6 , with 1 corresponding to total disagreement and 6 to total agreement. Thus, the maximum score possible is 102, which higher scores corresponding to better interpersonal relations. The items are related to two dimensions: sociability (refers to behavioral aspects of interpersonal relations at work) 
and feeling about oneself (related to intrapersonal feelings, relations developed with peers at work). The scale authors found a Cronbach's alpha coefficient of 0.866 for the sociability dimension and 0.72 for the feeling about oneself dimension, in a sample of 213 nurses. In the present study, in the sociability dimension, Cronbach's alpha corresponded to 0.848 , against 0.840 in the feeling about oneself dimension and iii) the nurse stress index (NSI), version 1.1, translated to Portuguese. The NSI comprises 30 items with a fivepoint Likert scale. It is subdivided in five sub-scales: 1 - management of workload (MW). This sub-scale assesses the pressure felt regarding insufficient time and resources to complete tasks; 2 - organizational support and involvement (OSI). This sub-scale defines the pressure felt due to the lack of involvement in planning and execution decisions and, also, questions regarding lack of adequate feedback at work; 3 - dealing with patients and relatives (DPR). In that sub-scale, three main problems are identified: nurses' ambivalence as to how to deal with death and dying patients, the nurse/ patient relation and increasing violence in nursing; 4 - home/work conflicts (HWC). This sub-scale assesses problems resulting from conflicting demands originating at home and work and 5 - confidence and competency in role (CCR). This includes role difficulties felt, such as the organizational change process, lack of confidence in one's skills, or uncertainty regarding one's responsibility area or degree. The obtained results grant knowledge on stress scores. The higher the score, the higher the stress levels will be. In the present study, the Cronbach's alpha coefficient of the total scale corresponded to 0.919. As for the sub-scales, the following Cronbach's alpha coefficients were found: management of workload 0.823 , organizational support and involvement 0.738 , dealing with patients and relatives 0.717 , home/work conflicts 0.726 and confidence and competency in role 0.648 .

Regarding ethical procedures, a written request was sent to the Board of Directors of the two study hospitals, after a previous meeting to provide information on the study goals, guaranteeing the confidentiality of results and the respondents' anonymity. The study was authorized with a positive opinion from both hospitals: reference 03471, issued on February $13^{\text {th }} 2009$ and reference $027 / 09$ (019-DEFI/025-CES), issued on May $14^{\text {th }} 2009$. It should be highlighted that participation in the study was strictly voluntary, and that nurses signed an informed consent term about their participation. Data were collected between May and August 2009.
As for data treatment, initially, univariate analysis (descriptive statistics) was used through absolute frequencies, central trend (means) and dispersion (standard deviation) measures. For the hypothesis test, the chi-square independence test was used to analyze the association between categorical variables, Student's t-test and one-way Anova to compare the means for continuous variables, and Mann-Whitney and KruskalWallis to compare the distribution of continuous variables between two or more than two independent groups, respectively, in case of asymmetric distribution of continuous variables, as well as Spearman's correlation coefficient for associations among continuing variables. Significance was set at 0.05 for all hypothesis tests. SPSS $®$ software, version 17.0 (Statistical Package for the Social Sciences) was used for data analysis.

\section{Results}

Out of 235 investigated nursing professionals, $71 \%$ work at hospital A and 29\% at hospital B. Most participants are women (77\% and single $(60 \%)$, the mean age is 29 years. Most participants hold a teaching diploma (95\%) and 3\% a Master's degree. In hospital A, $78 \%$ are women, like in hospital $B$, were $74 \%$ are women. The same similarities continue for age and academic degrees. In this study, higher stress levels are observed among female than among male nurses ( $\bar{X}=80$ vs. $\bar{X}$ $=77$ ). These differences are not statistically significant though (Student's t-test, $p=0.267$ ). The analysis of each NSI dimension and the existing relation with gender showed a statistically significant difference between gender and the dimension of dealing with patients and family members $(p=0.010)$. It was also observed that age does not influence stress levels in nurses (Spearman's correlation coefficient, $r=-0.013 ; p=0.849$ ). With regard to marital status, nurses living with a fixed partner show the highest stress levels ( $\bar{X}=89$; sd=17), followed by divorced ( $\bar{X}=87 ; \mathrm{sd}=30$ ) and married ( $\bar{X}=78 ; \mathrm{sd}=17$ ) and, finally, single nurses ( $\bar{X}=79 ;$ sd $=18$ ). Differences, however, are not statistically significant (one-way Anova test, $p=0.267)$. The analysis of each NSI dimension and the existing relation with marital status revealed a statistically significant difference between civil status and the dimension of dealing with patients and relatives $(p=0.010)$, as nurses who are divorced or live with a fixed partner perceive the dimension of dealing with patients and family members as a source of stress.

As for data related to the physical aspects of the service, natural light is present at most intensive 
care units of the two study hospitals, that is, outward facing windows. Nurses at hospital B work under more natural light, with a statistically significant difference $(p=0.003)$. Of 235 investigated nurses, 71\% mention that noise interferes in their activities, provoking lack of concentration (54\%), greater irritability (17\%), increased stress and fatigue (15\%). Considering workers' needs, most nurses (54\%) indicate that the physical structure is inadequate.

As observed in Table 1, the presence of natural light at the service does not influence nurses' stress index (Student's t-test, $\mathrm{p}=0.404$ ). With regard to the existing relation between the interference of noise in activities and nurses' stress index, the same test revealed that noise leads to higher stress levels ( $\bar{X}=81 ; \mathrm{sd}=18$ ), but without statistically significant differences $(p=0.076)$. It is also certain that nurses with higher stress indices can be more sensitive to noise. As for the relation between the physical structure and nurses' stress indices, it was observed that nurses who work in an inappropriate physical structure experience higher stress indices $(\bar{X}=83 ; \mathrm{sd}=17)$. These differences are statistically significant $(p<0.001)$, based on which one may say that an association exists between stress and perceived inadequate physical structure.

Table 1 - Distribution of nurses' stress index according to physical aspects at the service. Porto, 2009

\begin{tabular}{lcccc}
\hline & $\mathbf{5}$ & $\bar{X}$ & sd & $\boldsymbol{P}$ \\
\cline { 2 - 5 } & $\mathbf{n}$ & $\bar{X}$ & 19 & 0.404 \\
\hline $\begin{array}{l}\text { Natural light at the service stress index (NSI) } \\
\text { Yes }\end{array}$ & 204 & 80 & 14 & \\
No & 24 & 77 & & \\
Interference of noise in activities & 160 & 81 & 18 & 0.076 \\
Yes & 68 & 76 & 18 & \\
$\quad$ No & 104 & 75 & 19 & $<0.001$ \\
The physical structure at your service is & & 17 & \\
Adequate & 123 & 83 & & \\
Inadequate & & & & \\
\hline
\end{tabular}

With regard to data related to the work context, regarding the professional category, 65\% are nurses at the start of their career, that is, with less than 6 years of professional experience, $26 \%$ are graduated nurses with more than 6 years of professional experience and $10 \%$ are nurse specialists (hold a specialization degree in nursing). Nurses at the start of their career show higher stress levels ( $\bar{X}=81 ; \mathrm{sd}=17)$ than graduated nurses ( $\bar{X}=79 ; \mathrm{sd}=19$ ) or nurse specialists ( $\bar{X}=70$; $\mathrm{sd}=18$ ). Statistically significant differences are observed (one-way Anova, $p=0.020$ ), considering that nurses at the start of their career experience higher stress indices (Table 2). No statistically significant association exists between professional experience and nurses' stress index ( $r=-0.023 ; p=0.727)$, nor between nurses' absenteeism and stress levels (Spearman's correlation coefficient, $r=-0.224 ; p=0.305)$. No statistically significant relation exists (Kruskal-Wallis test, $p=0.471$ ) between nurses' work relation and stress levels, although nurses working on a limited job contract experience higher stress levels ( $\bar{X}=88$ ) than nurses working on a permanent contract) $(\bar{X}=77)$. The differences found between nurses' function accumulation and stress index are not statistically significant (Student's t-test, $p=0.745$ ), although it should be mentioned that nurses without function accumulation experience higher stress levels than nurses who do accumulate different functions (Table 2). The presence of incentives like salary raises and payment of congress registration fees, for example, does not influence nurses' stress levels, as the results found are not statistically significant (Student's t-test, $p=0.441$ ), although nurses without incentives show higher stress levels. The differences found in work time, i.e. working mornings or afternoons only, or shift work (mornings, afternoons and nights) and stress levels are not statistically significant (Student's t-test, $\mathrm{p}=0.139$ ). Nevertheless, nurses working shifts experience higher stress levels ( $\bar{X}=80$ ) (Table 2 ).

Table 2 - Distribution of nurses' stress indices according to professional category, function accumulation, work time, incentives and type of contract. Porto, 2009

\begin{tabular}{lcccc}
\hline & \multicolumn{5}{c}{ Nurse Stress Index (NSI) } \\
\cline { 2 - 5 } & $\mathbf{n}$ & $\bar{X}$ & sd & $\mathbf{p}$ \\
\hline Professional category & & & & \\
$\quad$ Early-career nurses & 147 & 81 & 17 & 0.020 \\
Graduated nurses & 58 & 79 & 19 & \\
Specialist nurses & 23 & 70 & 18 & \\
Function accumulation at another service/institution & & \\
Yes & 88 & 79 & 19 & 0.745 \\
No & 139 & 80 & 18 & \\
Work time & & & & \\
Fixed time & 20 & 74 & 17 & 0.139 \\
$\quad$ Shift work & 208 & 80 & 18 & \\
Presence of incentives & & & & \\
Yes & 21 & 77 & 22 & 0.441 \\
$\quad$ No & 206 & 80 & 18 & \\
\hline
\end{tabular}


As for data regarding the of Interpersonal Work Relations Scale (ERIT) and the Nurse Stress Index - NSI), the analysis of answers to the Interpersonal Relations at Work Scale showed maximum scores of 60 and minimum scores of 18 in the sociability dimension. In the feeling about oneself dimension, the maximum score was 40 and the minimum 7 (Table 3). On the nurse stress index, the minimum score was found on the organizational support and involvement, dealing with patients and relatives, home/work conflicts and confidence and competency in role (Table 3 ).

Table 3 - Distribution of nurses regarding ERIT and NSI scores. Porto, 2009

\begin{tabular}{|c|c|c|c|c|c|}
\hline & $\mathbf{n}$ & $\bar{X}$ & sd & $\min$. & $\max$ \\
\hline \multicolumn{6}{|l|}{ ERIT - subscales } \\
\hline Sociability & 234 & 44 & 7 & 18 & 60 \\
\hline Feeling about oneself & 232 & 26 & 7 & 7 & 40 \\
\hline \multicolumn{6}{|l|}{ NSI - subscales } \\
\hline $\begin{array}{l}\text { Organizational support and } \\
\text { involvement }\end{array}$ & 234 & 15 & 4 & 5 & 25 \\
\hline $\begin{array}{l}\text { Dealing with patients and family } \\
\text { members }\end{array}$ & 234 & 14 & 4 & 5 & 24 \\
\hline Home/work conflicts & 234 & 12 & 4 & 5 & 23 \\
\hline $\begin{array}{l}\text { Confidence and competency } \\
\text { in role }\end{array}$ & 233 & 13 & 4 & 5 & 23 \\
\hline Workload management & 233 & 26 & 7 & 11 & 43 \\
\hline
\end{tabular}

To validate whether the workload was associated with the nurse stress index, the Spearman correlation coefficient was used, which revealed a strong and positive association between the described variables ( $r=-0.905$; $p=<0.001$ ), based on which it can be inferred that higher workloads are linked with higher stress levels among nurses. It should also be highlighted that, among NSI dimensions, the workload is most strongly associated with nurses' stress levels (Table 4).

Table 4 - Spearman correlation coefficient between NSI and respective subscales. Porto, 2009

\begin{tabular}{ccccccc}
\hline & OSI & LDP & HWC & CCR & $\begin{array}{c}\text { MW1 and } \\
\text { MW2 }\end{array}$ & $\begin{array}{c}\text { Nurse } \\
\text { stress index } \\
\text { (NSI) }\end{array}$ \\
\hline OSI & & & & & & \\
$r$ & 1.000 & $0.502^{*}$ & $0.466^{*}$ & $0.604^{*}$ & $0.661^{*}$ & $0.789^{*}$ \\
$p$ & - & $<0.001$ & $<0.001$ & $<0.001$ & $<0.001$ & $<0.001$ \\
LDP & & & & & & \\
$r$ & $0.502^{*}$ & 1.000 & $0.507^{*}$ & $0.656^{*}$ & $0.614^{*}$ & $0.766^{*}$ \\
$p$ & $<0.001$ & - & $<0.001$ & $<0.001$ & $<0.001$ & $<0.001$ \\
& & & & & & (continue...)
\end{tabular}

Table 4 - (continuation)

\begin{tabular}{ccccccc}
\hline & OSI & LDP & HWC & CCR & $\begin{array}{c}\text { MW1 and } \\
\text { MW2 }\end{array}$ & $\begin{array}{c}\text { Nurse } \\
\text { stress index } \\
\text { (NSI) }\end{array}$ \\
\hline HWC & & & & & & \\
r & $0.466^{*}$ & $0.507^{*}$ & 1.000 & $0.610^{*}$ & $0.577^{*}$ & $0.740^{*}$ \\
p & $<0.001$ & $<0.001$ & - & $<0.001$ & $<0.001$ & $<0.001$ \\
CCR & & & & & & \\
r & $0.604^{*}$ & $0.656^{*}$ & $0.610^{*}$ & 1.000 & $0.760^{*}$ & $0.867^{*}$ \\
P & $<0.001$ & $<0.001$ & $<0.001$ & - & $<0.001$ & $<0.001$ \\
MW1 and MW2 & & & & & \\
R & $0.661^{*}$ & $0.614^{*}$ & $0.577^{*}$ & $0.760^{*}$ & 1.000 & $0.905^{*}$ \\
P & $<0.001$ & $<0.001$ & $<0.001$ & $<0.001$ & - & $<0.001$ \\
\hline *significant correlation coefficient at an 0.01 confidence level.
\end{tabular}

Regarding intensive care nurses' interpersonal relations and stress level, one may say that a low negative association exists between them (Spearman's correlation coefficient, $r=-0.331 ; p<0.001)$, which means that, the worse the relation, the higher the stress levels (Table 5). Also, regarding the interpersonal relation, the 66 nurses who establish a bad relation with their heads perceive the organizational support and involvement dimension as a stressor (Student's t-test, $\mathrm{p}<0.001$ ).

Table 5 - Spearman correlation coefficient between NSI and ERIT scores and their subscales. Porto, 2009

\begin{tabular}{cccc}
\hline \multicolumn{2}{c}{ ERIT } & Subscale: sociability & $\begin{array}{c}\text { Subscale: feeling } \\
\text { about oneself }\end{array}$ \\
\hline \multicolumn{2}{c}{ Nurse stress index $(\mathrm{NSI})$} & & \\
$\mathrm{R}$ & $-0.331^{*}$ & -0.035 & $0.303^{*}$ \\
$\mathrm{P}$ & $<0.001$ & 0.597 & $<0.001$ \\
\hline
\end{tabular}

*correlation coefficient significant at 0.01 confidence.

\section{Discussion}

Underlining the most significant study data, the following considerations are due.

The nurses' stress level at the two study hospitals was very similar (hospital A, $\bar{X}=79$; hospital B, $\bar{X}=80$ ). Also, women showed higher stress levels than men, in line with data from another study(17), although carried out more than ten years earlier.

As opposed to what other authors mentioned(9), which found a weak negative association between age and stress level, i.e. the younger, the lower the stress level, this study found no association between nurses' age and stress levels.

In line with another study and regarding marital status $^{(9)}$, most nurses are single (60\%). Nurses living with 
a fixed partner experience higher stress levels, followed by divorced, married and, finally, single nurses.

Regarding professional category, the present results contradict the results of another study ${ }^{(17)}$, as the former found higher stress levels among registered nurses than among graduated and specialist nurses.

With respect to professional experience at intensive care units, this study supports data other researchers ${ }^{(17-18)}$ found, demonstrating no association between this factor and nurses' stress levels.

As for absenteeism, most nurses do not miss work and, among those who did (10\%), stress levels do not seem to constitute the reason for, nor are they related with this variable. These results are opposed to another study ${ }^{(17)}$, which found higher means among nurses who had missed work.

With regard to the job contract, nurses working as service providers experience higher stress levels than nurses working on a permanent contract, in line with another study ${ }^{(17)}$

Most nurses (91\%) mention no professional incentives. Although it cannot be affirmed based on the differences found that a relation exists between these variables, nurses who do not receive incentives show higher stress levels.

Ninety-one percent of nurses work in shifts. They experience higher stress levels and perceive lack of time and insufficient resources to complete tasks as stressors.

In line with other studies(18-19), it is concluded that nurses working in an inappropriate physical structure face higher stress levels, including lack of space and noise deriving from ICU devices.

Among NSI dimensions, the workload is most strongly associated with nurses' stress levels. The association between these variables is strong and positive, based on which it can be inferred that the association between workload and stress levels is significant, showing that, the higher the workload, the higher the nurse stress levels. These results are in line with other researchers' findings(20-22). The greater valuation of the workload may be related with the type of care delivered to highly dependent patients and, mainly, with the capacity of intensive care units, due to the fact that hospital policies increasingly concentrate on the number of available places, independently of the specialties practiced there.

Regarding nurses' interpersonal relation, it was verified that, the worse the interpersonal relation, the higher the nurses' stress levels, with a statistically significant relation. Studies by other researchers ${ }^{(21,23)}$ also reveal that interpersonal relation represents a factor nurses consider a stressor. Thus, interpersonal relations at work represent an important aspect to focus on in nursing stress management.

\section{Conclusions}

Stress can entail repercussions at individual, social and organizational level, which appear in terms of absenteeism, turnover rate, decreased worker performance, decreased motivation and work satisfaction, increased number of occupational accidents and increased performance errors. The present study results appoint suggestions of organizational factors acting as stressors in intensive care nurses. The results were significant for the following variables: professional category, inadequate physical structure, workload management and interpersonal relations. It should also be taken into account that the present study data appoint the need for physical spaces adapted to workers' needs and more equitable incentives, as well as the need to increase nursing staff number in order to decrease the workload. Hence, it is important to put in practice occupational stress management intervention programs, which should integrate all operating areas and involve all collaborators, as people are the core of an organization, and their comprehensive involvement permits the use of their aptitudes to the benefit of the organization, thus contribution for the entity to reach its goals. It is important and fundamental to examine the stress sources, so as to prevent adverse reactions that can affect not only professionals' health and wellbeing, but also professional performance and, therefore, the quality of patient care.

\section{References}

1. Vaz Serra A. Stress e bem estar. Lisboa: Climpsi Editores; 2005.

2. Santos AM, Castro JC. Stress. Análise Psicol. 1998;4(16):675-90.

3. Vaz Serra A. O stress na vida de todos os dias. Coimbra: Edições Minerva; 2002.

4. Frasquilho AM. Stress e médicos: sal da vida ou morte anunciada?. Mundo Médico. 2003; 27: 60-3.

5. European Commission. Guidance on work-related stress: Spice of live - or Kiss of Death?. Luxembourg EU - Directorate General for Employment and Social Affairs; 1999. 
6. Sacadura-Leite E, Uva, AS. Stress relacionado com o trabalho. Saúde \& Trabalho. 2007;6: 25-42.

7. Urden LD, Stacy KM. Enfermagem de cuidados intensivos: Diagnóstico e intervenção ( $5^{\mathrm{a} e d .}$.). Lisboa: Lusodidacta; 2008.

8. Ung EK, Kua EH. Mental Health. In: Jeyaratnam J, Koh D, editors. Texbook of Occupational Medicine Practice. Singapura: Wold Scientific Pub; 2001.

9. Cavalheiro AM, Moura DF Júnior, Lopes AL. Stress in nurses working in intensive care units. Rev. Latino-Am. Enfermagem. 2008;16(1):29-35.

10. Martins M. Situações indutoras de stress no trabalho dos enfermeiros em ambiente hospitalar; 2009. [acesso 13 março 2009]. Disponível em: www.ipv.pt/millenium/ millenium28/18.htm.

11. Amorim RC, Silvério IP. Perspectiva do paciente na unidade de terapia intensiva na admissão e alta. Rev Paul Enferm. 2003;22(2):209-12.

12. Martins JT, Robazzi MC. Nurses' work in intensive care units: feelings of suffering. Rev. Latino-Am. Enfermagem. 2009;17(1):52-8.

13. Gratton L. Palavras ao vento. Exame. 2000;34(15):36-40.

14. Nascimento KC, Erdmann AL. Understanding the dimensions of intensive care: transpersonal caring and complexity theories. Rev. Latino-Am. Enfermagem. 2009;17(2):215-21.

15. Nishide VM, Malta MA, Aquino KS. Aspectos organizacionais em unidade de terapia intensiva. In: Cintra EA, Nishide VM, Nunes WA. Assistência de enfermagem a paciente gravemente enfermo. Rio de Janeiro: Atheneu; 2001.

16. Oliveira AC, Cardoso CS, Mascarenhas D. Intensive care unit professionals' knowledge and behavior related to the adoption of contact precautions. Rev. Latino-Am. Enfermagem. 2009;17(5):625-31.

17. Fernandes MD. Avaliação do stress nos enfermeiros de cuidados intensivos. [Dissertação de Mestrado em Saúde Ocupacional]. Coimbra: Faculdade de Medicina; 1996.

18. Guerrer FJ, Bianchi ER. Caracterização do estresse nos enfermeiros de unidades de terapia intensiva. Rev Esc Enferm USP. 2007;42(2):355-62.

19. Queirós P. O que causa mal-estar, stress, em enfermeiros? Rev Invest Enferm. 2003;8:3-7.

20. Tyson PD, Pongruengphant R. Five-yar follow-up stydy of stress among nurses in public and private hospitals in Thailand. Int J Nurs Stud. 2004;41:247-54.
21. Makie V. Stress and coping strategies amongst registered nurses working in South Africa Tertiary Hospital. [Dissertação de Mestrado]. Western Cape: Faculdade de Ciências da Saúde - Universidade de Western Cape; 2006.

22. Aguiar VE, Pons RM, Echegaray MC, Ramos DB, Dánchez RF. Estresores laborales y bien estar psicológico. Rol Enferm. 2000;23(7-8):506-11.

23. Kawano Y. Association of Job-related stress factors with psychological and somatic symptoms among japanese hospital nurses: Effects of departmental environment in acute care hospitals. J Occup Health. 2008; 50:79-85.
Received: Sep. $1^{\text {st }} 2010$ Accepted: May $2^{\text {nd }} 2011$ 